\title{
ST-Segment Resolution after Primary Percutaneous Coronary Intervention: Characteristics, Predictors of Failure, and Impact on Mortality
}

\author{
Pedro Beraldo de Andrade 1 , Fábio Salerno Rinaldi², Marcos Henriques Bergonso ${ }^{3}$, \\ Marden André Tebet ${ }^{4}$, Ederlon Ferreira Nogueira ${ }^{5}$, Vinícius Cardozo Esteves ${ }^{6}$, \\ Igor Ribeiro de Castro Bienert ${ }^{7}$, Mônica Vieira Athanazio de Andrade ${ }^{8}$, Robson Alves Barbosa ${ }^{9}$, \\ Luiz Alberto Piva e Mattos ${ }^{10}$, André Labrunie ${ }^{11}$
}

\begin{abstract}
Background: ST-segment resolution is an important predictor of infarct-related artery patency and effective microcirculatory perfusion. The aim of this study was to compare patients with and without ST-segment elevation resolution and identify variables that are associated with failure of ST-segment resolution. Methods: Between March 2012 and July 2013, 61 patients with ST-segment elevation acute myocardial infarction underwent primary percutaneous coronary intervention $(\mathrm{PCl})$ and were included in a prospective registry. To compare the groups with and without ST-segment resolution, the chi-square test or Fisher's exact test were used for qualitative variables and Student's t test or Mann-Whitney's test for quantitative variables. Simple and multiple logistic regression models were used to identify variables associated with failure of ST-segment resolution. Results: The group of patients without ST-segment resolution had higher heart rate, higher prevalence of diabetes mellitus, chronic renal failure and a trend towards longer ischemia time. There was a higher mortality rate in patients who did not achieve ST-segment elevation resolution. In the univariate analysis, heart rate, diabetes mellitus, chronic renal failure and ischemia time were associated with increased odds of not obtaining ST-segment resolution, losing significance in the multivariate model. Conclusions: Failure of ST-segment resolution is observed in up to one-third of patients undergo-
\end{abstract}

RESUMO

Resolução do Segmento ST após Intervenção
Coronária Percutânea Primária: Características,
Preditores de Insucesso e Impacto na Mortalidade

Introdução: A resolução do segmento ST é um importante preditor de patência da artéria relacionada ao infarto e de perfusão efetiva da microcirculação. O objetivo deste trabalho foi comparar pacientes com e sem resolução do segmento ST e identificar variáveis que se associam à não resolução do ST. Métodos: Entre março de 2012 e julho de 2013, 61 pacientes com infarto agudo do miocárdio com elevação do segmento ST foram submetidos à intervenção coronária percutânea (ICP) primária e incluídos em um registro prospectivo. Para comparar os grupos com e sem resolução do segmento ST, foi utilizado o teste qui-quadrado ou exato de Fisher, para as variáveis qualitativas, e o teste t de Student ou de Mann-Whitney, para variáveis quantitativas. Para identificar variáveis associadas à não resolução do ST, foram ajustados modelos de regressão logística simples e múltipla. Resultados: O grupo de pacientes sem resolução do segmento ST apresentou maior frequência cardíaca, maior prevalência de diabetes mellitus, de insuficiência renal crônica e tendência a maior tempo de isquemia. Observou-se maior mortalidade hospitalar entre pacientes que não obtiveram resolução do

\footnotetext{
${ }^{1}$ Postgraduate student (Doctoral). Interventionist Cardiologist Physician at Santa Casa de Marília. Marília, SP, Brazil.

2 Interventionist Cardiologist Physician at Santa Casa de Marília. Marília, SP, Brazil.

${ }^{3}$ Cardiologist Trainee at Santa Casa de Marília. Marília, SP, Brazil.

${ }^{4}$ Interventionist Cardiologist Physician at Rede D'Or São Luiz. São Paulo, SP, Brazil.

5 Interventionist Cardiologist Physician at Hospital do Coração de Londrina. Londrina, PR, Brazil.

${ }^{6}$ Interventionist Cardiologist Physician at Rede D'Or São Luiz. São Paulo, SP, Brazil.

7 Technician Director of the Interventionist Cardiology Service of Hospital das Clínicas da Faculdade Estadual de Medicina de Marília. Marília, SP, Brazil.
}

\footnotetext{
${ }^{8}$ Nurse, Specialist in Cardiovascular Nursing at Santa Casa de Marília Marília, SP, Brazil.

${ }^{9}$ Nurse, Specialist in Cardiovascular Nursing at Santa Casa de Marília. Marília, SP, Brazil.

${ }^{10}$ Doctor. Interventionist Cardiologist Physician at Rede D'Or São Luiz. São Paulo, SP, Brazil.

${ }^{11}$ Doctor. Interventionist Cardiologist Physician at Coração de Londrina. Londrina, PR, Brazil
}

Correspondence to: Pedro Beraldo de Andrade. Av. Vicente Ferreira, 828 - Marília, SP, Brazil - CEP 17515-900

E-mail: pedroberaldo@gmail.com

Received on: 7/1/ 2013 • Accepted on: 9/4/2013 
ing primary $\mathrm{PCl}$ and requires new pharmacologic strategies or interventions to minimize it.
DESCRIPTORS: Myocardial infarction. Percutaneous coronary intervention. Myocardial reperfusion.
ST. Pela análise univariada, as variáveis frequência cardíaca, diabetes mellitus, insuficiência renal crônica e tempo de isquemia associaram-se à maior chance de não resolução do ST, perdendo significância no modelo multivariado. Conclusões: A não resolução do segmento ST pode ocorrer em até um terço dos pacientes submetidos à ICP primária, requerendo o advento de novas estratégias farmacológicas ou de intervenção capazes de minimizá-la.

DESCRITORES: Infarto do miocárdio. Intervenção coronária percutânea. Reperfusão miocárdica.
$\mathrm{C}$ ompared to fibrinolysis, percutaneous coronary intervention $(\mathrm{PCl})$ promotes a more early and sustained restoration of epicardial flow in the target vessel, and is widely accepted as the preferred strategy in the treatment of acute myocardial infarction (AMI). ${ }^{1,2}$ The resolution of the ST-segment after the institution of reperfusion therapy is an important predictor of patency of the artery related to the event and of effective microcirculatory perfusion. ${ }^{3}$

The analysis of ST-segment resolution on the electrocardiogram (ECG) consists of a simple tool, of easy use and low cost, able to document success of the epicardial reperfusion and tissue reperfusion after primary $\mathrm{PCl}^{4}{ }^{4}$ The persistence of ST-segment elevation on the ECG, despite the restoration of a normal epicardial flow, signifies a poor prognosis; such persistence is known to be associated with larger infarct size and higher combined rate of severe cardiovascular adverse events. ${ }^{5}$

In a contemporary context for the application of primary $\mathrm{PCl}$, characterized by an aggressive antithrombotic therapy, manual aspiration thrombectomy, intracoronary adenosine, and ample use of the radial access, this study aimed to determine the percentage of failure in ST-segment resolution, its predictors, and the impact on in-hospital and late mortality.

\section{METHODS}

Between March 2012 and July 2013, patients with AMI with ST-segment elevation $\geq 1 \mathrm{~mm}$ in two contiguous leads of the frontal plane or $\geq 2 \mathrm{~mm}$ in precordial leads, with symptoms duration $<12$ hours, underwent primary $\mathrm{PCl}$ and were included in a local controlled prospective registry. A 12-lead ECG, plus leads V3R, $\mathrm{V} 4 \mathrm{R}, \mathrm{V} 7$, and $\mathrm{V} 8$ in the case of lower AMI, was performed at admission and 30 to 60 minutes after the conclusion of the procedure. Patients with left branch block or pacemaker rhythm, surgical myocardial revascularization, cardiogenic shock, or life expectation $<$ six months were excluded. The electrocardiographic analysis followed the prevalent normative guidelines, ${ }^{6}$ considering complete a ST-segment resolution $>70 \%$.
This study aimed to compare demographic and procedure-related characteristics of patients with and without complete ST-segment resolution after performing primary $\mathrm{PCl}$, and to identify the variables that were associated to non-ST-resolution. The secondary objective was to determine its impact on infarct size, measured by maximum peak of CK-MB, length of stay, and in-hospital mortality after 30 days, six months and one year of follow-up.

Ischemia time was defined as the interval between the onset of symptoms and the crossing of the lesion with a pre-dilation balloon, manual thrombus aspiration catheter, or stent. Door-to-balloon time was defined as the interval between hospital admission and the crossing of the lesion with a pre-dilation balloon catheter, manual thrombus aspiration catheter, or stent. A CK-MB analysis was performed every six hours until the occurrence of a reduction in the levels of this biomarker. The choice of antiplatelet therapy, use of prophylactic intracoronary adenosine, manual aspiration thrombectomy, and the access route were left to the discretion of the surgeon.

\section{Statistical Analysis}

Qualitative variables were summarized as absolute frequencies and percentages. The quantitative data were expressed as means \pm standard deviation or medians and interquartile ranges (25th percentile -75 th percentile) according to distribution for each variable. To compare the groups with and without resolution of the ST-segment, the chi-squared test or Fisher's exact test were used for qualitative variables, and Student's $t$-test or the Mann-Whitney test were used for quantitative variables.

To identify variables associated with ST-segment resolution, simple (univariate approach) and multiple (multivariate analysis) logistic regression models were adjusted. The results were expressed as odds ratios (OR) and $95 \%$ confidence intervals $(95 \% \mathrm{Cl})$. The level of significance was 0.05 . The statistical program used to perform the calculations was the SPSS for Windows, version 19.0 . 
TABLE 1

Baseline clinical characteristics

\begin{tabular}{|c|c|c|c|c|}
\hline Variables & $\begin{array}{l}\text { General } \\
(n=61)\end{array}$ & $\begin{array}{l}\text { ST-segment } \\
\text { resolution } \\
(n=44)\end{array}$ & $\begin{array}{l}\text { Non-ST-segment } \\
\text { resolution } \\
(n=17)\end{array}$ & $\mathbf{P}$ \\
\hline Male, n (\%) & $34(55.7)$ & $26(59.1)$ & $8(47.1)$ & 0.40 \\
\hline Age, years & $58.8 \pm 10.8$ & $59.2 \pm 11.2$ & $57.6 \pm 9.8$ & 0.61 \\
\hline $\mathrm{BMI}, \mathrm{kg} / \mathrm{m}^{2}$ & $28.0 \pm 4.6$ & $27.8 \pm 4.9$ & $28.5 \pm 4.0$ & 0.60 \\
\hline HR, bpm & $82.4 \pm 17.1$ & $79.4 \pm 16.4$ & $90.1 \pm 16.7$ & 0.03 \\
\hline Hypertension, n (\%) & $42(68.9)$ & $30(68.2)$ & $12(70.6)$ & 0.86 \\
\hline Diabetes mellitus, n (\%) & $19(31.1)$ & $10(22.7)$ & $9(52.9)$ & 0.02 \\
\hline Currently smoking (\%) & $24(39.3)$ & $20(45.5)$ & $4(23.5)$ & 0.12 \\
\hline Prior AMI, n (\%) & $3(4.9)$ & $3(6.8)$ & 0 & 0.55 \\
\hline Prior $\mathrm{PCl}, \mathrm{n}(\%)$ & $3(4.9)$ & $3(6.8)$ & 0 & 0.55 \\
\hline Creatinine, mg/dL & $0.81(0.67-1.06)$ & $0.79(0.64-1.02)$ & 0.89 (0.76-1.49) & 0.15 \\
\hline Chronic renal failure, n (\%) & $7(11.5)$ & $2(4.5)$ & $5(29.4)$ & 0.02 \\
\hline
\end{tabular}

$\mathrm{BMI}=$ body mass index; $\mathrm{HR}=$ heart rate; $\mathrm{bpm}=$ beats per minute; $\mathrm{AMI}=$ acute myocardial infarction; $\mathrm{PCl}=$ percutaneous coronary intervention.

\section{RESULTS}

\section{Comparisons among patients with and without ST-segment resolution}

Table 1 shows a comparison among patients with and without ST-segment resolution regarding baseline clinical characteristics. It was observed that the group of patients without ST-segment resolution had, on average, a higher heart rate and higher prevalence of diabetes mellitus and of chronic renal failure.

With respect to the procedure and angiographic characteristics (Table 2), a statistically significant difference was observed only in the number of stents used. A trend of longer ischemia time among patients without ST-segment resolution $(4.7 \pm 2.0$ hours vs. 6.3 \pm 3.1 hours; $P=0.07$ ) was detected.

Regarding the results and the clinical outcome, a higher in-hospital mortality rate among patients who did not achieve ST-segment resolution was observed (Table 3).

\section{Identification of variables associated with non-ST segment resolution}

This part of the analysis sought to identify, among the clinical, angiographic and procedural characteristics, the factors associated with the increased probability of non-ST-segment resolution. Initially, the isolated effect of each variable were investigated by simple logistic regression models (univariate analysis), considering as dependent variable the non-ST-segment resolution. The results are shown in Table 4.
As expected, according to the comparison between groups, the variables heart rate, diabetes mellitus, and chronic renal failure were associated with increased probability of non ST-segment resolution. In addition, the ischemia time was also significant. The variables prior $\mathrm{AMI}$, prior $\mathrm{PCl}$, route of access, and therapeutic catheters could not be analyzed due to the low frequency in some of their categories.

Variables with $\mathrm{P}<0.20$ in the univariate analysis were selected for the multivariate model, in which the effects were analyzed simultaneously (Table 5). In this model, all variables lost their importance and ceased to be significant according to the usual significance level of 0.05 . This can be explained by the low statistical power to detect differences, caused by the increase in the number of parameters in the model.

In order to obtain a more consistent model, the non-significant variables were excluded, step-by-step, until the achievement of a reduced model. In this model, only diabetes $(\mathrm{OR}=3.83,95 \% \mathrm{Cl}, 1.17$ to $12.51, \mathrm{P}=$ $0.19)$ and chronic renal failure $(\mathrm{OR}=8.75,95 \% \mathrm{Cl}, 1.50$ to $50.90, \mathrm{P}=0.15)$ remained significant. Importantly, although they were significant, the estimates were not very accurate (very wide Cls), and the ORs may be overestimated. Still, it is clear that diabetes mellitus and chronic renal failure are factors associated with non-ST-segment resolution.

\section{DISCUSSION}

Incomplete ST-segment resolution after primary $\mathrm{PCl}$ correlates strongly with mortality and reinfarction, 
TABLE 2

Angiographic and procedure characteristics

\begin{tabular}{|c|c|c|c|c|}
\hline Variables & $\begin{array}{l}\text { General } \\
(n=61)\end{array}$ & $\begin{array}{l}\text { ST-segment } \\
\text { resolution } \\
(n=44)\end{array}$ & $\begin{array}{l}\text { Non-ST-segment } \\
\text { resolution } \\
(n=17)\end{array}$ & $\mathbf{P}$ \\
\hline Killip I, n (\%) & $57(93.4)$ & $41(93.2)$ & $16(94.1)$ & $>0.99$ \\
\hline Location of AMI, n (\%) & & & & 0.72 \\
\hline Anterior & $30(49.2)$ & $21(47.7)$ & $9(52.9)$ & \\
\hline Inferior & $31(50.8)$ & $23(52.3)$ & $8(47.1)$ & \\
\hline Hemoglobin, g/dL & $13.7 \pm 1.9$ & $13.9 \pm 1.9$ & $13.1 \pm 2.0$ & 0.15 \\
\hline CK-MB activity, U/L & $51.5(26.9-115)$ & $52.3(27-107.5)$ & $48.2(23-121)$ & 0.94 \\
\hline Ischemia time, hours & $5.1 \pm 2.4$ & $4.7 \pm 2.0$ & $6.3 \pm 3.1$ & 0.07 \\
\hline Door-to-balloon time, min & $55(42-75)$ & $56.5(43.5-80)$ & $50.0(42-65)$ & 0.40 \\
\hline $\begin{array}{l}\text { Manual aspiration } \\
\text { thrombectomy, n (\%) }\end{array}$ & $33(54.1)$ & $23(52.3)$ & $10(58.8)$ & 0.45 \\
\hline Direct stent implantation, $\mathrm{n}(\%)$ & $27(44.3)$ & $21(47.7)$ & $6(35.3)$ & 0.38 \\
\hline Visible aspirated, n (\%) & $19(31.1)$ & $14(31.8)$ & $5(29.4)$ & 0.86 \\
\hline Prophylactic adenosine, n (\%) & $22(36.1)$ & $16(36.4)$ & $6(35.3)$ & 0.94 \\
\hline TIMI pre-0 or $1, \mathrm{n}(\%)$ & $49(80.3)$ & $37(84.1)$ & $12(70.6)$ & 0.29 \\
\hline Radial access, n (\%) & $60(98.4)$ & $43(97.7)$ & $17(100)$ & $>0.99$ \\
\hline GPI IIb/IIla, n (\%) & $35(59.3)$ & $24(57.1)$ & $11(64.7)$ & 0.59 \\
\hline Left ventriculography, n (\%) & & & & 0.55 \\
\hline Not evaluated & $8(13.1)$ & $6(13.6)$ & $2(11.8)$ & \\
\hline Normal & $18(29.5)$ & $13(29.5)$ & $5(29.4)$ & \\
\hline Mild dysfunction & $16(26.2)$ & $11(25.0)$ & $5(29.4)$ & \\
\hline Moderate dysfunction & $16(26.2)$ & $13(29.5)$ & $3(17.6)$ & \\
\hline Severe dysfunction & $3(4.9)$ & $1(2.3)$ & $2(11.8)$ & \\
\hline Culprit vessel, n (\%) & & & & $>0.99$ \\
\hline Left anterior descending artery & $29(47.6)$ & $21(47.7)$ & $8(47.1)$ & \\
\hline Right coronary artery & $19(31.1)$ & $14(31.8)$ & $5(29.4)$ & \\
\hline Left circumflex artery & $12(19.7)$ & $8(18.2)$ & $4(23.5)$ & \\
\hline Intermediate branch & $1(1.6)$ & $1(2.3)$ & 0 & \\
\hline P2Y12 blocker, n (\%) & & & & 0.70 \\
\hline Clopidogrel 300 mg & $4(6.6)$ & $3(6.8)$ & $1(5.9)$ & \\
\hline Clopidogrel 600 mg & $38(62.3)$ & $26(59.1)$ & $12(70.6)$ & \\
\hline Ticagrelor $180 \mathrm{mg}$ & $19(31.1)$ & $15(34.1)$ & $4(23.5)$ & \\
\hline Number of diagnostic catheters & $1(1-2)$ & $1(1-2)$ & $1(1-2)$ & 0.91 \\
\hline Diagnostic catheters, n (\%) & & & & $>0.99$ \\
\hline 1 & $44(72.1)$ & $32(72.7)$ & $12(70.6)$ & \\
\hline 2 or more & $17(27.9)$ & $12(27.3)$ & $5(29.4)$ & \\
\hline Number of therapeutic catheters & $1(1-1)$ & $1(1-1)$ & $1(1-1)$ & 0.15 \\
\hline Therapeutic catheters, n (\%) & & & & 0.31 \\
\hline 1 & $56(91.8)$ & $39(88.6)$ & $17(100.0)$ & \\
\hline 2 or 3 & $5(8.2)$ & $5(11.4)$ & 0 & \\
\hline Number of stents & $1(1-1)$ & $1(1-1)$ & $1(1-1)$ & 0.01 \\
\hline Number of stents, n (\%) & & & & $<0.01$ \\
\hline 0 & $4(6.6)$ & 0 & $4(23.5)$ & \\
\hline 1 & $50(82.0)$ & $38(86.4)$ & $12(70.6)$ & \\
\hline 2 or 3 & $7(11.5)$ & $6(13.6)$ & $1(5.9)$ & \\
\hline Contrast volume, $\mathrm{mL}$ & $185.8 \pm 64.1$ & $187.8 \pm 66.4$ & $180.6 \pm 59.2$ & 0.70 \\
\hline
\end{tabular}


TABLE 3

Outcomes of efficacy, safety, and evolution

\begin{tabular}{|c|c|c|c|c|}
\hline Variables & $\begin{array}{l}\text { General } \\
(n=61)\end{array}$ & $\begin{array}{l}\text { ST-segment } \\
\text { resolution } \\
(n=44)\end{array}$ & $\begin{array}{l}\text { Non-ST-segment } \\
\text { resolution } \\
(n=17)\end{array}$ & $\mathbf{P}$ \\
\hline TIMI 3post, n (\%) & $51(83.6)$ & $39(88.6)$ & $12(70.6)$ & 0.12 \\
\hline CK-MB peak, U/L & $285.9 \pm 206.2$ & $295.2 \pm 194.6$ & $261.9 \pm 238.4$ & 0.58 \\
\hline Length of hospital stay, nights & $3(3-4)$ & $3(3-4)$ & $4(3-5)$ & 0.53 \\
\hline Complications, n (\%) & $6(9.8)$ & $3(6.8)$ & $3(17.6)$ & 0.34 \\
\hline In-hospital mortality, n (\%) & $4(6.6)$ & 0 & $4(23.5)$ & $<0.01$ \\
\hline \multicolumn{5}{|l|}{ Clinical events at 30 days, $\mathrm{n}(\%)$} \\
\hline Patients & 51 & 38 & 13 & \\
\hline Events & $1(1.9)$ & $1(2.6)$ & 0 & $>0.99$ \\
\hline \multicolumn{5}{|l|}{ Clinical events at six months, n (\%) } \\
\hline Patients & 37 & 28 & 9 & \\
\hline Events & $3(8.1)$ & $3(10.7)$ & 0 & 0.55 \\
\hline Clinical events at one year, $\mathrm{n}(\%)$ & & & & $>0.99$ \\
\hline Patients & 24 & 17 & 7 & \\
\hline Events & $2(8.3)$ & $2(11.8)$ & 0 & \\
\hline
\end{tabular}

regardless of the degree of patency of the target vessel. ${ }^{5}$ In a series from real-world practice, characterized by a mean age of 59 years, $31 \%$ diabetics, $11 \%$ with chronic renal failure, ischemia time of 5 hours, and median door-to-balloon time of 55 minutes, the rate of obtaining a final Thrombolysis in Myocardial Infarction (TIMI) flow 3 was $84 \%$, with ST-segment resolution $>70 \%$ in $72 \%$ of the sample. Diabetes mellitus, chronic renal failure, elevated heart rate, longer ischemic time, and fewer implanted stents were the characteristics most commonly observed in patients who did not achieve ST-segment resolution; the first two factors are important predictors of failure.

In pre-specified analysis of the randomized trial "Harmonizing Outcomes with Revascularization and Stents in Acute Myocardial Infarction" (HORIZONS$\mathrm{AMI}$ ), comprising 2,484 of 3,345 patients undergoing primary $\mathrm{PCl}$, the rate of resolution of ST-segment > $70 \%$ was $50.5 \%$, with a lower incidence of death, reinfarction, target vessel revascularization, and stent thrombosis at three years in this group. ${ }^{7}$ In the same clinical trial, final TIMI flow 3 was achieved in $87.1 \%$ of the sample, and age, anterior wall AMI, TIMI pre$0 / 1$, and extent of injury were independent predictors of final TIMI flow $<3$ by multivariate analysis. ${ }^{8}$ In an Argentinean multicenter registry, despite obtaining a final TIMI flow 3 in $90 \%$ of the sample, the rate of complete ST-segment resolution was $48.5 \% .^{9}$

The present series displays characteristics that differ from those previously mentioned, which could explain the high percentage of complete ST-segment resolution. Initially, the sample of patients undergoing the procedure was restricted to within 12 hours after onset of symptoms. The mean ischemia time was 5.1 hours and the median door-to-balloon time was only 55 minutes, favored by the logistical conditions set forth in a previous publication. ${ }^{10}$ Moreover, manual aspiration thrombectomy was used in $54 \%$ of the sample, and glycoprotein IIb/IIla inhibitors and adenosine were administered prophylactically to $59 \%$ and $36 \%$ of cases, respectively.

In fact, in the electrocardiographic sub-analysis of the trial Platelet Inhibition and Patient Outcomes (PLATO), ${ }^{11} 70 \%$ of patients randomized in the interval of 3-6 hours from the onset of symptoms exhibited ST-segment resolution, compared to $51 \%$ of those randomized after 6 hours. Meanwhile, a meta-analysis including 18 randomised trials and 3,936 patients showed that manual thrombus aspiration, compared to conventional primary $\mathrm{PCl}$, promotes higher TIMI 3 final myocardial blush $(63.6 \%$ vs. $48.5 \% ; \mathrm{P}<0.0001)$ and higher complete ST-segment resolution $(55.8 \%$ vs. 44.3\%; P $<0.0001) .{ }^{12}$

Glycoprotein IIb/IIla inhibitors, despite lack of consistent evidence to justify their routine indication, find an application niche in patients classified as high risk. ${ }^{13,14}$ Finally, in the "Intracoronary Nitroprusside Versus Adenosine in Acute Myocardial Infarction"(REOPEN-AMI) randomized trial, $71 \%$ of patients who received intracoronary adenosine after thrombus aspiration exhibited ST-segment resolution $>70 \%$, compared to $54 \%$ in the group receiving sodium nitroprusside and to $51 \%$ of 
TABLE 4

Factors associated with non-ST-segment resolution (univariate analysis)

\begin{tabular}{|c|c|c|c|}
\hline Variables & OR & $95 \% \mathrm{Cl}$ & $\mathbf{P}$ \\
\hline Male & 0.62 & $(0.20-1.90)$ & 0.40 \\
\hline Age, years & 0.99 & $(0.94-1.04)$ & 0.61 \\
\hline Body mass index, $\mathrm{kg} / \mathrm{m}^{2}$ & 1.03 & $(0.92-1.17)$ & 0.59 \\
\hline Heart rate, $\times 10 \mathrm{bpm}$ & 1.47 & $(1.03-2.10)$ & 0.03 \\
\hline Hypertension & 1.12 & $(0.33-3.80)$ & 0.86 \\
\hline Diabetes mellitus & 3.83 & $(1.17-12.51)$ & 0.03 \\
\hline Current smoking & 0.37 & $(0.10-1.31)$ & 0.12 \\
\hline Creatinine, mg/dL & 1.10 & $(0.74-1.62)$ & 0.64 \\
\hline Chronic renal failure & 8.75 & $(1.50-50.90)$ & 0.02 \\
\hline Killip I & 1.17 & $(0.11-12.10)$ & 0.90 \\
\hline Infarction, anterior location & 1.23 & $(0.40-3.78)$ & 0.72 \\
\hline Hemoglobin on admission, g/dL & 0.80 & $(0.60-1.08)$ & 0.15 \\
\hline CK-MB activity on admission, U/L & 1.00 & $(0.10-1.01)$ & 0.33 \\
\hline Ischemia time, hours & 1.31 & $(1.03-1.68)$ & 0.03 \\
\hline Door-to-balloon time, $\min$ & 0.10 & $(0.98-1.02)$ & 0.86 \\
\hline Manual aspiration thrombectomy & 1.30 & $(0.42-4.05)$ & 0.65 \\
\hline Direct stent implantation & 0.60 & $(0.19-1.90)$ & 0.38 \\
\hline Macroscopic aspirate visible & 0.89 & $(0.26-3.03)$ & 0.86 \\
\hline Prophylactic adenosine & 0.96 & $(0.30-3.07)$ & 0.94 \\
\hline TIMI pre- 2 or 3 & 2.20 & $(0.59-8.24)$ & 0.24 \\
\hline Glycoprotein Ilb/IIla inhibitor & 1.38 & $(0.43-4.42)$ & 0.59 \\
\hline Moderate or severe LV & 0.89 & $(0.26-3.03)$ & 0.86 \\
\hline \multicolumn{4}{|l|}{ Culprit vessel } \\
\hline Right coronary & 1.00 & - & - \\
\hline Left Circumflex artery/intermediate branch & 1.24 & $(0.26-5.92)$ & 0.78 \\
\hline Left anterior Descending artery & 1.07 & $(0.29-3.94)$ & 0.92 \\
\hline \multicolumn{4}{|l|}{$\mathrm{P} 2 \mathrm{Y}_{12}$ blocker on admission } \\
\hline Ticagrelor $180 \mathrm{mg}$ & 1.00 & - & - \\
\hline Clopidogrel 300 mg & 1.25 & $(0.10-15.50)$ & 0.86 \\
\hline Clopidogrel 600 mg & 1.73 & $(0.47-6.34)$ & 0.41 \\
\hline 2 or more diagnostic catheters & 1.11 & $(0.32-3.83)$ & 0.87 \\
\hline 2 or more stents & 0.40 & $(0.04-3.56)$ & 0.41 \\
\hline
\end{tabular}

TABLE 5

Factors associated with non-ST-segment resolution. Results of simple (univariate analysis) and multiple (multivariate analysis) logistic regression models

\begin{tabular}{|c|c|c|c|c|c|c|}
\hline \multirow[b]{2}{*}{ Factors } & \multicolumn{3}{|c|}{ Univariate } & \multicolumn{3}{|c|}{ Multivariate } \\
\hline & OR & $95 \% \mathrm{CI}$ & $\mathbf{P}$ & OR & $95 \% \mathrm{Cl}$ & $\mathbf{P}$ \\
\hline Heart rate, $\times 10$ bpm & 1.47 & $(1.03-2.10)$ & 0.03 & 1.42 & $(0.93-2.18)$ & 0.11 \\
\hline Diabetes mellitus & 3.83 & $(1.17-12.51)$ & 0.03 & 2.55 & $(0.63-10.31)$ & 0.19 \\
\hline Current smoking & 0.37 & $(0.10-1.31)$ & 0.12 & 0.55 & $(0.12-2.46)$ & 0.43 \\
\hline Chronic renal failure & 8.75 & $(1.50-50.90)$ & 0.02 & 4.41 & $(0.57-33.97)$ & 0.15 \\
\hline Hemoglobin at admission, g/dL & 0.80 & $(0.60-1.08)$ & 0.15 & 0.84 & $(0.55-1.28)$ & 0.41 \\
\hline Ischemia time, hours & 1.31 & $(1.03-1.68)$ & 0.03 & 1.22 & $(0.90-1.65)$ & 0.21 \\
\hline
\end{tabular}

OR = odds ratio; IC 95\% = confidence interval of $95 \%$. 
the saline group $(P=0.009)$, limiting the reperfusion injury, as measured by the occurrence of angiographic microvascular obstruction (TIMI flow $\leq 2$ or 3 with TIMI myocardial blush <2). ${ }^{15}$

\section{Limitations of the study}

Apart from the non-random sampling, the main limitation of this study resided in the small size of their sample, making it impossible to identify potential determinant variables for failure of complete ST-segment resolution after primary $\mathrm{PCI}$.

\section{CONCLUSIONS}

Incomplete resolution of ST-segment may occur in up to one-third of patients undergoing primary percutaneous coronary intervention, regardless of the restoration of TIMI 3 final epicardial flow. The predictor variables diabetes mellitus, chronic renal failure, heart rate, and ischemia time are associated with incomplete resolution of ST-segment elevation, requiring new pharmacological or interventional strategies to minimize this condition.

\section{CONFLICTS OF INTEREST}

The authors declare no conflicts of interest.

\section{REFERENCES}

1. Steg PG, James SK, Atar D, Badano LP, Lundqvist CB, Borger MA, et al. ESC Guidelines for the management of acute myocardial infarction in patients presenting with ST-segment elevation. The Task Force on the management of St-segment elevation acute myocardial infarction of the European Society of Cardiology (ESC). Eur Heart J. 2012;33(20):2569-619.

2. O'Gara PT, Kushner FG, Ascheim DD, Casey Jr DE, Chung MK, Lemos JA, et al. 2013 ACCF/AHA guideline for the management of ST-elevation myocardial infarction: a report of the American College of Cardiology Foundation/American Heart Association Task Force on Practice Guidelines. Circulation. 2013;127(4):e362-425.

3. Hallén J, Sejersten M, Johanson P, Atar D, Clemmensen PM. Influence of ST-segment recovery on infarct size and ejection fraction in patients with ST-segment elevation myocardial infarction receiving primary percutaneous coronary intervention. Am J Cardiol. 2010;105(9):1223-8.

4. Feldman LJ, Coste P, Furber A, Dupouy P, Slama MS, Monassier JP, et al. Incomplete resolution of ST segment elevation is a marker of transient microcirculatory dysfunction after stenting for acute myocardial infarction. Circulation. 2003;107(21):2684-9.

5. McLaughlin MG, Stone GW, Aymong E, Gardner G, Mehran R, Lansky AJ, et al. Prognostic utility of comparative methods for assessment of ST-segment resolution after primary angioplasty for acute myocardial infarction The Controlled Abciximab and Device Investigation to Lower Late Angioplasty Complications (CADILLAC) trial. J Am Coll Cardiol. 2004;44(6):1215-23.

6. Pastore CA, Pinho C, Germiniani H, Samesima N, Mano R, et al.; Sociedade Brasileira de Cardiologia. Diretrizes da Sociedade Brasileira de Cardiologia sobre Análise e Emissão de Laudos Eletrocardiográficos (2009). Arq Bras Cardiol. 2009; 93(3 Supl.2):1-19.

7. Farkouh ME, Reiffel J, Dressler O, Nikolsky E, Parise H, Cristea E, et al. Relationship between ST-segment recovery and clinica outcomes after primary percutaneous coronary intervention: the HORIZONS-AMI ECG substudy report. Circ Cardiovasc Interv. 2013;6(3):216-23.

8. Caixeta A, Lansky A, Mehran R, Brener SJ, Claessen B, Généreux $P$, et al. Predictors of suboptimal TIMI flow after primary angioplasty for acute myocardial infarction: results from the HORIZONS-AMI trial. Eurolntervention. 2013;9(2):220-7.

9. Damonte AA, Lasave L, Kozak F, Rossi M, Gamen M, Cura F, et al. Avaliação da resolução do supradesnivelamento do segmento ST após angioplastia primária: Registro Multicêntrico de Infarto Agudo do Miocárdio com Supradesnivelamento do Segmento ST na Argentina. Rev Bras Cardiol Invasiva. 2009;17(4):470-5.

10. Andrade PB, Tebet MA, Nogueira EF, Rinaldi FS, Esteves VC, Andrade MVA, et al. Impacto da transferência inter-hospitalar nos resultados da intervenção coronária percutânea primária. Rev Bras Cardiol Invasiva. 2012;20(4):361-6.

11. Armstrong PW, Siha H, Fu Y, Westerhout CM, Steg PG, James SK, et al. ST-elevation acute coronary syndromes in the Platelet Inhibition and Patient Outcomes (PLATO) trial: insights from the ECG substudy. Circulation. 2012; 125(3):514-21.

12. Kumbhani DJ, Bavry AA, Desai MY, Bangalore S, Bhatt DL. Role of aspiration and mechanical thrombectomy in patients with acute myocardial infarction undergoing primary angioplasty: an updated meta-analysis of randomized trials. J Am Coll Cardiol. 2013 May 8. [Epub ahead of print].

13. Ortolani P, Marzocchi A, Marrozzini C, Palmerini T, Saia F, Taglieri N, et al. Long-term effectiveness of early administration of glycoprotein Ilb/IIla agents to real-world patients undergoing primary percutaneous interventions: results of a registry study in an ST-elevation myocardial infarction network. Eur Heart J. 2009;30(1):33-43.

14. Sethi A, Bajaj A, Bahekar A, Bhuriya R, Singh M, Ahmed A, et al. Glycoprotein IIb/IIla inhibitors with or without thienopyridine pretreatment improve outcomes after primary percutaneous coronary Intervention in high-risk patients with ST elevation myocardial infarction:a meta-regression of randomized controlled trials. Catheter Cardiovasc Interv. 2013; 82(2):171-81.

15. Niccoli G, Rigattieri S, Vita MRD, Valgimigli M, Corvo P, Fabbiocchi F, et al. Open-label, randomized, placebo-controlled evaluation of intracoronary adenosine or nitroprusside after thrombus aspiration during primary percutaneous coronary intervention for the prevention of microvascular obstruction in acute myocardial infarction: the REOPEN-AMI Study (Intracoronary Nitroprusside Versus Adenosine in Acute Myocardial Infarction). JACC Cardiovasc Interv. 2013;6(6):580-9. 